\title{
Selective estrogen receptor modulators: tissue specificity and clinical utility
}

This article was published in the following Dove Press journal:

Clinical Interventions in Aging

28 August 2014

Number of times this article has been viewed

\author{
Stephen Martinkovich* \\ Darshan Shah* \\ Sonia Lobo Planey \\ John A Arnott
}

Department of Basic Sciences, The Commonwealth Medical College, Scranton, PA, USA

*These authors contributed equally to this work
Correspondence: John A Arnott Department of Basic Sciences, The Commonwealth Medical College, 525 Pine Street, Scranton, PA 18509 USA Tel +l 5705049675

Fax +I 5705049660

Email jarnott@tcmedc.org

\begin{abstract}
Selective estrogen receptor modulators (SERMs) are a diverse group of nonsteroidal compounds that function as agonists or antagonists for estrogen receptors (ERs) in a target gene-specific and tissue-specific fashion. SERM specificity involves tissue-specific expression of ER subtypes, differential expression of co-regulatory proteins in various tissues, and varying ER conformational changes induced by ligand binding. To date, the major clinical applications of SERMs are their use in the prevention and treatment of breast cancer, the prevention of osteoporosis, and the maintenance of beneficial serum lipid profiles in postmenopausal women. However, SERMs have also been found to promote adverse effects, including thromboembolic events and, in some cases, carcinogenesis, that have proven to be obstacles in their clinical utility. In this review, we discuss the mechanisms of SERM tissue specificity and highlight the therapeutic application of well-known and emergent SERMs.
\end{abstract}

Keywords: selective estrogen receptor modulators, SERMs, estrogen receptors

\section{Introduction}

Estrogens play critical roles in development, reproduction, cognition, and growth and maintenance of the skeleton. Research suggests that estrogens and their intracellular receptors (ERs), $\mathrm{ER} \alpha$ and $\mathrm{ER} \beta$, may also influence pathophysiologic states of multiple tissues by contributing to diseases including cancer (eg, breast, endometrial, prostate, and colorectal), cardiovascular and metabolic diseases, cognitive diseases such as Alzheimer's, and osteoporosis. ${ }^{1,2}$ Estrogens have been effective in their clinical use as oral contraception, fertility treatment, and hormone therapy in menopause. However, they are contraindicated in some patients due to their multiple effects on various target tissues and implication as a risk factor in the development of breast and uterine cancers.

Selective estrogen receptor modulators (SERMs) are a diverse group of nonsteroidal compounds that function as ligands for ERs. However, unlike estrogens that function as ER agonists differing primarily in potency, SERMs have the unique ability to selectively act as agonists or antagonists in a target gene and in a tissue-specific fashion. ${ }^{3-5}$ Thus, the pharmacological advantage of SERMs lies in this mixed agonism/ antagonism profile that affords the beneficial estrogenic actions in target tissues and avoids adverse, off-target effects. This mixed agonism/antagonism profile is the result of differentially expressed ER, ligand-dependent receptor conformational changes, and various interactions with co-activators and co-repressors expressed or recruited in a tissue-specific fashion. ${ }^{6}$ Thus each SERM has a distinctive biological effect on its target tissue and since no class effect is associated with their function, each must be evaluated individually. ${ }^{7}$ The development of SERMs has extended the application of estrogen-related therapy and positively impacted how estrogen-related diseases are 
treated. To date, the major clinical applications of SERMs are their use in the prevention and treatment of breast cancer, the prevention of osteoporosis, and maintenance of beneficial serum lipid profiles in postmenopausal women. However, SERMs have also been found to promote adverse effects, mainly thromboembolic events and, in some cases, carcinogenesis. These adverse effects present a major obstacle in treatment with SERMs, especially in cases where long-term treatment (ie, osteoporosis) would be most desirable. This has led to the production of new-generation SERMs that are structurally distinct from their predecessors. The ideal SERM would have strong anti-estrogenic effects on breast cancer and endometrial cancers while stimulating the formation of bone in an estrogenic manner. The ability to design a drug that encompasses all of these qualities has proven difficult, as each drug produced seems to lack one of these important characteristics. Therefore, a clearer understanding of SERM's tissue dependent mechanism and signaling are needed to provide insight into developing SERMs with fewer negative side effects. This review will present the mechanistic approaches utilized by SERMs to achieve tissue specificity and highlight the therapeutic application of well-known and emergent SERMs.

\section{SERMs: mechanism of tissue specificity}

SERM tissue specificity is the culmination of several factors, mainly tissue-specific expression of ER subtypes (ie, ER $\alpha$ and ER $\beta$ ), differential expression of co-regulatory proteins in various tissues (ie, co-activators and co-repressors), and varying ER conformational changes induced by ligand binding $^{6}$ (Figure 1). These factors result in the ability of the therapeutic application of SERMs that can have discrete effects depending on the target tissue. However, these factors also complicate the understanding of individual SERM mechanisms of action and add to the challenge of designing new SERMs.

For decades it was generally accepted that there was only one ER gene coding for ER $\alpha$ which bound estrogen with high affinity. However, with the discovery of ER $\beta,{ }^{8}$ the

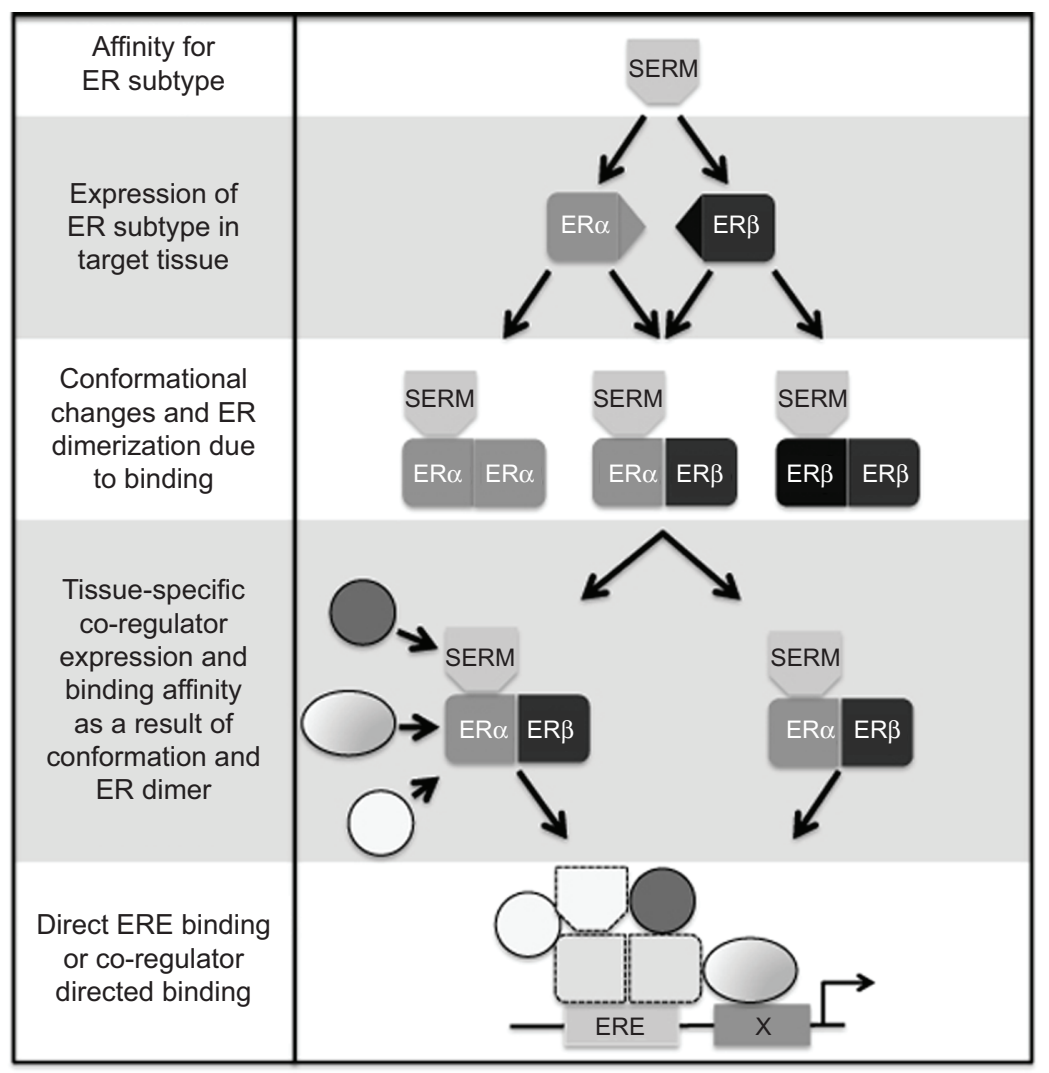

Figure I Model for SERM tissue specificity.

Notes: SERM tissue specificity depends on numerous factors: I) SERMs have differential and specific affinity for ER subtypes; 2) ER subtypes are differentially expressed in target tissues and can be heterogeneously expressed in a particular tissue; 3) SERM binding induces specific conformational changes in ER that influence dimerization and binding to various co-factors that can determine resultant target gene $(X)$ activation or repression; 4) Co-factors (ie, activators and repressors) are differentially expressed in target tissues; and 5) ER-SERM complexes can bind directly to an ERE or be directed to bind other transcriptional motifs as a result of binding to various co-factors. Abbreviations: ER, estrogen receptor; ERE, estrogen response element; SERM, selective estrogen receptor modulators. 
possibility that any selective effect of estrogen could be due to the differential expression of these two ER genes caused a paradigm shift in our understanding of the estrogen signaling system, and made understanding the differential expression of these genes in estrogen-sensitive tissues a major focus of research..$^{8-12}$ The relative tissue expression of ER $\alpha$ and ER $\beta$ are important determinants of a tissue's response to estrogen. $E R \alpha$ and $E R \beta$ exert differential effects on growth and differentiation in tissues, including bone, colon, uterus, liver, brain, and mammary gland. ${ }^{13-19}$ For example, ER $\alpha$ is believed to have a proliferative role, whereas ER $\beta$ has an anti-proliferative role in transfected breast cancer cells. ${ }^{20}$ Certain tissues, such as hepatocytes in the liver and neural cells in the hippocampus, express high levels of $E R \alpha$, while in tissues like prostate, ovary, and lung, ER $\beta$ is expressed at high levels and ER $\alpha$ at low levels. ${ }^{21,22}$ Yet, in mammary gland, bone, uterus, the central nervous system, and the cardiovascular system, both ER $\alpha$ and ER $\beta$ show equally significant levels of expression and, additionally, can influence each other's functions. ${ }^{23-25}$ In certain tissues, such as testes and mammary glands, both the ER $\alpha$ and ER $\beta$ are expressed, but their cellular distribution is distinct. For example, in mammary glands, ER $\beta$ is mostly present in epithelial cell nuclei. In testis, ER $\alpha$ is reported to be localized in the nuclei of the Leydig cells, while ER $\beta$ is found in germ cells, Sertoli cells, and fetal Leydig cells. ${ }^{26}$ Thus the mechanism of action of estrogens and SERMs due to the contributions of either ERo and/or ER $\beta$ receptor has been difficult to determine.

The ligand-dependent molecular mechanism of SERMs is similar to that of $17 \beta$-estradiol and involves binding to its ligand-dependent nuclear ER. ERs have a large and flexible binding pocket that allows for multiple ligands to bind, including steroids, phytoestrogens, and xenobiotics. ${ }^{27}$ Ligand-bound ERs undergo a conformational change in their hormone binding domain that promotes dimerization and activation of the receptor which can then exert its effects either by binding directly to the estrogen response element (EREs), usually located in the promoter region of target genes, or by binding to co-regulator proteins at their respective promoter sites. ${ }^{28-31}$ The association of the ER with DNA can either positively or negatively regulate target gene transcription. $\mathrm{ER} \alpha$ and $\mathrm{ER} \beta$, including its various isoforms $(\beta 1, \beta 2, \beta 4$, and $\beta 5)$, are homologous members of the nuclear receptor superfamily that possess a modular structure and are composed of three major functional domains - the N-terminal domain (NTD), the DNA binding domain (DBD), and the ligand binding domain (LBD) - that serve specific roles. ${ }^{32}$ In terms of sequence homology, ER $\beta$ shows a high homology to $\mathrm{ER} \alpha$ in the $\mathrm{DBD}$ and in the $\mathrm{LBD} ;^{11,12}$ however, the NTD of $E R \beta$ is shorter than that of ER $\alpha$ with very poor sequence homology to that of ER $\alpha$. It is believed that full transcriptional activity of the ERs occurs through synergism between the two activation function (AF) domains, AF1 and AF2, located in the NTD and LBD respectively, ${ }^{33}$ and activity of the AFs occurs in a tissue and promoter specific fashion. ${ }^{34,35}$ AF1 functions in a hormone-independent manner, whereas AF2 function requires the presence of a ligand. ${ }^{36}$ In addition to the NTD, DBD, and LBD, the ERs consist of "hinge and F" regions. The "hinge" region contains a nuclear localization signal and serves as a flexible region connecting the DBD and LBD. The " $F$ " region, which contains 42 amino acids, is located towards the $\mathrm{C}$-terminal end of the LBD and possesses specific modulation capabilities of gene transcription in a ligand-, promoter-, and tissue-specific manner. ${ }^{37-39}$

The differences in ligand-induced transcriptional activation of target genes by ER $\alpha$ and ER $\beta$ may be a result of independent activation of the AF1 and AF2 (LBD) domains. ${ }^{31}$ $\mathrm{AF} 1$ and AF2, working together or independently, are able to recruit transcriptional co-regulator proteins following receptor stimulation. ${ }^{31}$ Co-regulator proteins are able to physically interact with the liganded or unliganded ER and modulate transcription of a gene. The recruitment of co-activator proteins such as SRC1 and SRC3, or co-repressor proteins such as nuclear receptor co-repressor ( $\mathrm{NCoR}$ ) or thyroid hormone receptor (SMRT), can either activate or repress transcriptional activity, respectively. ${ }^{31,40-43}$ Furthermore, it appears that regulatory proteins are selectively activated depending on both ER subtype and ligand binding activity. Using phage display, it was determined that ligand binding appears to place the ER in a unique position that alters the biological activity of co-regulatory proteins. ${ }^{44}$ For example, co-crystallization studies with various ligands determined that ERs that are bound to antagonists undergo a three-dimensional repositioning of helix 12 that can interfere with the receptor-co-regulatory protein interaction. ${ }^{45,46}$ There have currently been over 300 regulator proteins identified, and their interactions within ER transcriptional regulation are complex. ${ }^{47,48}$ Furthermore, the recruitment of co-regulator proteins is dependent on the specific ER ligand eliciting a unique receptor confirmation. ${ }^{49}$ This recruitment is thought to occur through an ordered, cyclical, and combinatorial process, and therefore, transcriptional activation by ERs can occur through cooperation between both AFs or through each AF independently. ${ }^{50}$ The activity of co-regulator proteins is also influenced by post-translational modification, such as phosphorylation, sumoylation, ubiquitination, and acetylation, which affect 
their ability to influence ER signaling. ${ }^{51-53}$ Therefore, the differential actions seen between ER $\alpha$ and ER $\beta$ may partially be a result of the structural difference between AF1 and AF2, and tissue dependent activities may be dependent on the expression of co-regulator proteins. ${ }^{40}$

The high degree of sequence homology within the DBD of $E R \alpha$ and $E R \beta$ results in the ability for both receptors to bind EREs with high affinity ${ }^{40,54,55}$ as either an ER $\alpha /$ ER $\alpha$ homodimer, $\mathrm{ER} \beta / \mathrm{ER} \beta$ homodimer, or an $\mathrm{ER} \alpha / \mathrm{ER} \beta$ heterodimer. ${ }^{5-57}$ Each composition of dimer that is formed is believed to mediate distinct hormonal responses, and different tissues express varying degrees of ER subtypes. Therefore, the ability for SERMs to display a selective affinity for ER subtypes based on affinity for a particular AF2 (LBD) may partially explain the tissue specificity of SERMs. Furthermore, it also appears that a single ligand bound receptor is capable of forming a homo- or heterodimer. ${ }^{58}$ This indicates that a SERM having an affinity for one of the ER subtypes may still be able to form an $\mathrm{ER} \alpha / \mathrm{ER} \beta$ heterodimer, and as a result, alter response to ligand binding; although, the exact impact of heterodimerization is still unclear. ${ }^{58}$ In some situations, response to estrogen stimulation depended on the co-presence of both ER $\alpha$ and ER $\beta$, suggesting that receptor heterodimerization may alter receptor signaling, possibly by allowing access to new chromatin regions. ${ }^{56}$ Moreover, the discovery of multiple ER $\beta$ various isoforms $(\beta 1, \beta 2, \beta 4$, and $\beta 5$ ) with differing tissue distribution and function further adds to the alternative results of ER stimulation. ${ }^{58}$

\section{Triphenylethylene SERMs \\ Tamoxifen}

Tamoxifen is a nonsteroidal triphenylethylene compound that was the first SERM to be used successfully to prevent and treat breast cancer. It quickly became the treatment of choice for ER $\alpha$ positive breast cancer and to reduce the risk of breast cancer in high-risk patients. ${ }^{59,60}$ Tamoxifen was first developed as an ER antagonist for breast cancer treatment. However the subsequent discovery of its agonist role in bone and the uterus spawned efforts to create SERMs with precise functions depending on tissue ${ }^{61,62}$ (Figure 2). Tamoxifen is routinely used to treat all stages of breast cancer. Adjuvant breast cancer trials have shown that tamoxifen's use reduced both breast cancer reoccurrence and contralateral breast cancer by $40 \%-50 \%{ }^{63}$ Tamoxifen efficacy was further investigated

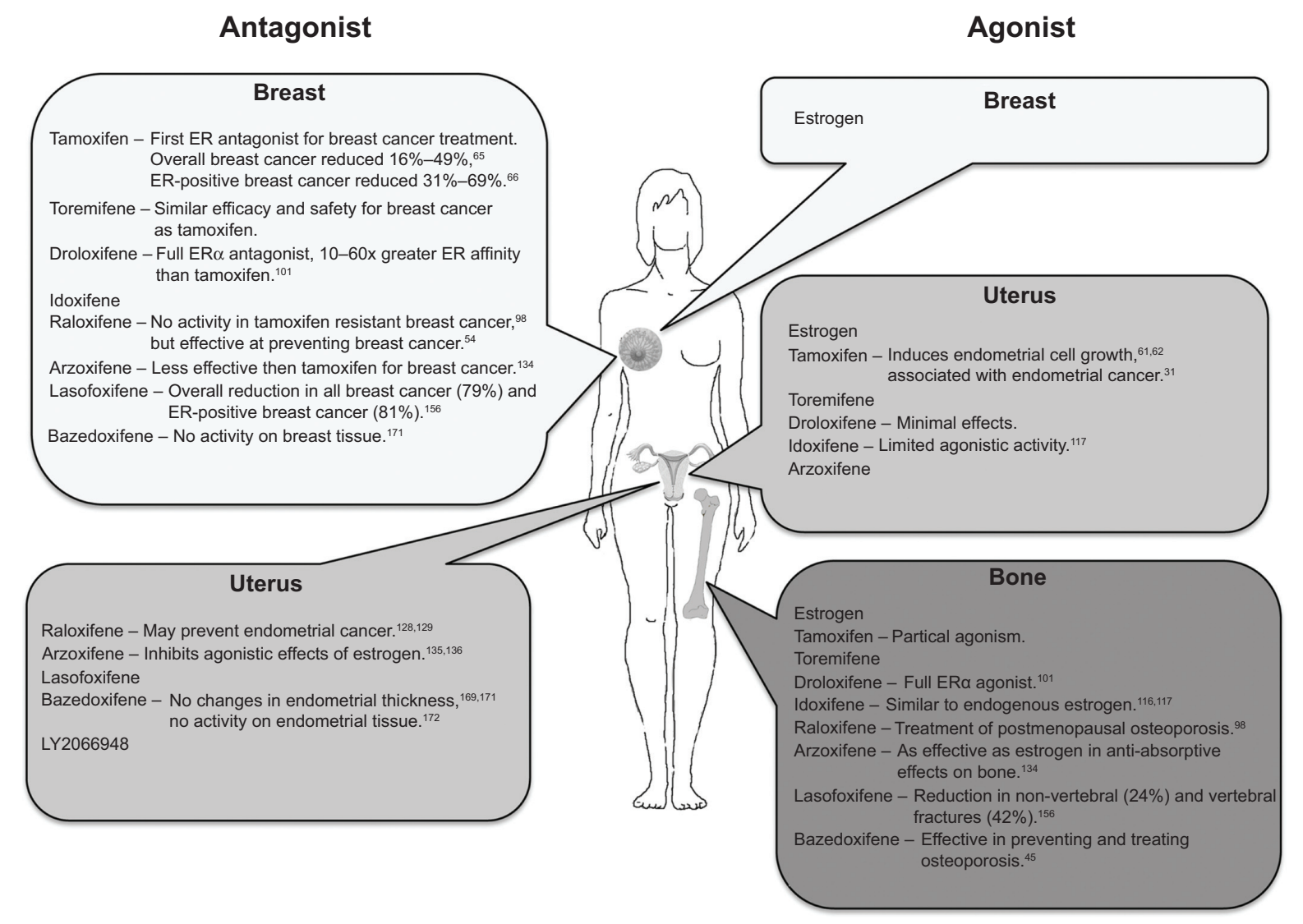

Figure 2 SERM tissue activity and clinical action in breast, uterus, and bone.

Abbreviations: ER, estrogen receptor; SERM, selective estrogen receptor modulators. 
in four major Phase III trials where it reduced overall breast cancer incidence between $16 \%$ and $49 \%$ and ER-positive breast cancer incidence between $31 \%$ and 69\%. ${ }^{64,65}$ Tamoxifen has also been determined to have a luteotropic effect if used by women in mid luteal phase and therefore is effective in reducing premenstrual mastalgia. ${ }^{66,67}$

The ability of tamoxifen to inhibit ER $\alpha$ positive breast cancer cell proliferation may be due to interaction with corepressors. Tamoxifen, similar to endogenous estrogens, requires metabolic activation by cytochrome $\mathrm{P} 450$ enzymes to form its active metabolites, 4-hydroxytamoxifen (4-OHT) and endoxifen. ${ }^{68} \mathrm{NCoR}$ and SMRT are co-repressor proteins that 4-OHT, a potent anti-estrogen, is known to recruit. ${ }^{49}$ Furthermore, in vivo inhibition of NCoR or SMRT and in vitro studies using fibroblasts from NCoR knockout mice, demonstrated an increase in antagonistic activity of 4-OHT. ${ }^{69,70}$ Additionally, the ability of 4-OHT to inhibit ER $\alpha$ breast cancer cell proliferation is impaired in NCoR and SMRT deficient cells. ${ }^{71}$ It is important to note that cells deficient in NCoR and SMRT do not show an activation of all estrogen dependent response genes, indicating that there are factors influencing SERM-induced repression that are important in this complex signaling. The mechanism of co-repression due to NCoR and SMRT is still being fully determined, but it appears that histone de-acetylase activity may be involved in this transcriptional repression. ${ }^{72,73}$ Repressor of estrogen action is another co-repressor potentiated by 4-OHT. When stimulated, resveratrol competes with the co-activator for binding to the estrogen bound ER and therefore potentiates 4-OHT as an estrogen antagonist. ${ }^{74,75}$

In uterine cells, tamoxifen acts as an estrogen agonist and induces growth of endometrial cells. ${ }^{61,62}$ In addition, tamoxifen can display beneficial partial agonistic effects on bones and the cardiovascular system in postmenopausal women. ${ }^{76}$ The difference in tamoxifen activity in each tissue is thought to be due to the expression of the co-regulator proteins such as SRC1, NCoR, or SMRT. SRC1, a co-activator promoted by tamoxifen, is highly expressed in uterine cells, but has low expression in breast cancer cells. ${ }^{72}$ This suggests that the stimulatory effect tamoxifen has on uterine cells may partially be explained by the distribution of co-activator proteins such as SRC1. This mechanism may also be contingent on the association of intrinsic histone acetyl transferase activity associated with SRC1 which helps activate transcriptional activity. ${ }^{77}$

Despite clinical success with tamoxifen, long-term tamoxifen use has been associated with an increased risk of endometrial cancer, as well as other side effects such as hot flashes, ocular changes, an increased risk of stroke, and pulmonary embolism..$^{29,78-82}$ In endometrial tissue, tamoxifen has partial estrogen-agonist properties and unopposed exogenous estrogens are known to be carcinogenic in the endometrium. ${ }^{83,84}$ Some of the adverse effects associated with tamoxifen have been attributed to its genotoxic metabolites. The increased incidence of endometrial cancer observed during tamoxifen administration are believed to be due to the formation of major DNA adducts. Tamoxifen may also mediate hepatocarcinogenesis by the formation of these DNA adducts. ${ }^{85-87}$ Tamoxifen resistance is also possible and can be achieved through either intrinsic resistance, where ER-positive breast cancer either never responds to treatment, or ER-positive breast cancer initially responds to treatment but subsequently acquires resistance. ${ }^{29}$

\section{Toremifene (chlorotamoxifen)}

Toremifene (TOR) is a nonsteroidal triphenylethylene SERM that is similar to tamoxifen in both structure and function. TOR differs from tamoxifen's structure in only a single chloride atom on its side group; a chloride atom substituted for a hydrogen atom in the ethyl group attached to part of the ethylene bond. ${ }^{88}$ TOR functions in a similar way to other Type I SERMs, displaying a higher affinity for ER $\alpha$ (about $5 \%$ of that of estradiol) than ER $\beta .^{89}$ It is an effective SERM for the treatment of breast cancer in postmenopausal women and may be therapeutically applicable in preventing fracture risk during hormone therapy. TOR may be a suitable alternative treatment for tamoxifen in hormone receptor-positive breast cancer in premenopausal women. A retrospective study comparing the efficacy and safety of TOR and tamoxifen in the treatment of operable hormone receptor-positive breast cancer in premenopausal women $(n=1,847)$ found that the TOR group $(n=396)$ and the tamoxifen group $(n=1,451)$ were similar in efficacy and safety. ${ }^{90}$ Furthermore, TOR lacks the DNA adduct-forming ability of tamoxifen and the genotoxicity of tamoxifen, suggesting that TOR has a lesser uterotrophic effect than tamoxifen, and it appears that TOR is not associated with an increased risk of endometrial cancer. ${ }^{91-95}$ Overall, TOR has been found to have similar efficacy to tamoxifen in treating advanced $\mathrm{ER} \alpha$ positive breast cancer, with a similar side effect profile. TOR has also been determined to have a luteotropic effect if used by women mid-luteal phase, and therefore is effective in reducing cyclic breast pain compared to placebo. ${ }^{67,96}$ Not surprisingly, due to the similarities between TOR and tamoxifen in structure and function, the two drugs are cross-reactive. In a doubleblind, cross over trial, 66 postmenopausal women were 
started on either TOR (140 mg/day) or tamoxifen (40 mg/ day). Forty-four of the women were then crossed over to the alternative treatment, and no response was achieved from either of the second line treatments. ${ }^{97}$ Additionally, in an international Phase III study evaluating TOR use in preventing vertebral fractures in men with non-metastatic prostate cancer being treated with androgen deprivation therapy, it was determined that TOR was associated with a reduced risk of vertebral fractures compared to placebo. However, in this investigation, TOR was also associated with an increased rate of venous thromboembolic events and therefore has not been approved for fracture prevention in men receiving androgen deprivation therapy. ${ }^{98}$ There have been reports that the differences in the actions of tamoxifen compared to TOR may be due to a lower estrogenic to antiestrogenic effect. ${ }^{99}$

\section{Droloxifene}

The goal in the production of droloxifene (3-[1-[4(2-Dimethylaminoethoxy)phenyl]-2-phenyl-but-1-enyl] phenol) was to make a version of tamoxifen that was more potent but had fewer side effects, such as liver tumors or the formation of DNA adducts. ${ }^{100}$ The differences between droloxifene and tamoxifen are the removal of methyl on the amino group and the addition of an alcohol at the third position. As a result of these changes, the drug has a 10-60× greater affinity for the ER and a shorter serum half-life than its parent molecule tamoxifen. With the greater level of affinity for the ER $\alpha$ receptor, it was thought that dosing periods could be shortened with droloxifene. ${ }^{100}$ Droloxifene is a full ER $\alpha$ antagonist in the breast and a full ER $\alpha$ agonist in bone. Similar to tamoxifen, droloxifene blocks cells in the G1 phase of the cell cycle thereby inhibiting their growth. ${ }^{101}$ Also similar to tamoxifen, it was shown to cause an increase in TGF- $\beta$ which in bone causes an increase in pre-osteoclast apoptosis and MCF-7 breast cancer cell apoptosis. ${ }^{102}$ Based on this finding, it can be hypothesized that droloxifene also causes an inhibition of insulin-like growth factor (IGF)-1 stimulated cell growth and prevents expression of estrogen stimulated oncogene c-myc, as these represent the mechanism of tamoxifen. In addition to being active in bone and breast, droloxifene was shown to have increased anti-estrogenic activity and lowered estrogenic activity in the immature rat uterus compared to tamoxifen. ${ }^{100}$ Through its preclinical trials, droloxifene showed promise in treating both breast and bone cancers while having minimal activity on uterine and endometrial tissues. In a Phase I trial conducted by Buzdar et al 30 patients were enrolled and received doses of 20, 40, 100,200 , or $300 \mathrm{mg}$. No patients noted objective responses, only four showed moderate responses and droloxifene was very well tolerated by the patients, even at the higher doses. ${ }^{103}$ Given that all the patients in the trial had previously failed tamoxifen therapy and had very few negative side effects from treatment, droloxifene was pursued in Phase II trials. In a randomized Phase II trial consisting of 369 postmenopausal women who were either ER positive or had unknown ER status, doses of 20, 40, or $100 \mathrm{mg}$ of droloxifene showed no significant differences. The average objective response across all doses was $39.3 \%{ }^{104}$ These positive results led to the Phase III trial for droloxifene. The major side effects noted for droloxifene were hot flashes, nausea, fatigue, headache, backpain, and dyspnea. ${ }^{103,105}$ The Phase III trial of droloxifene consisted of 1,354 patients across multiple countries. The trial once randomized had 673 patients in the tamoxifen group and 681 patients in the droloxifene group. The objective response rate was $18 \%$ for droloxifene and $23 \%$ for tamoxifen, indicating that droloxifene was not significantly better than tamoxifen in responses. Interestingly, both drugs were more efficacious in postmenopausal than premenopausal woman. In women younger than 65 years, the tumor response rates for droloxifene and tamoxifen were $15 \%$ and $23 \%$ respectively. In women older than 65 years, the response rate was $38 \%$ for both tamoxifen and droloxifene. ${ }^{106}$ The possible short comings of droloxifene in this trial for premenopausal women could have been due to the short half-life of droloxifene ( 1 day) leading to greater fluctuation in serum concentration. ${ }^{107,108}$ It is thought that this could be avoided with higher doses, as shown by several studies that show serum levels of sex hormones and binding proteins are concentration-dependent between 40 and $100 \mathrm{mg} .{ }^{107,108}$ This suggests that at higher doses, the drug is able to reach higher concentrations and even with equivalent excretion rates, maintain therapeutic levels for an extended period of time. In spite of this theory, the Phase III trial of droloxifene was closed at its second interim analysis as it was deemed to be ineffective in comparison to tamoxifen.

\section{Idoxifene}

Idoxifene ((E)-1-(2-(4-(1-(4-Iodophenyl)-2-phenylbut-1-en1 -yl)phenoxy)ethyl)pyrrolidine) was developed as an antiestrogen with lower estrogenic effects on endometrial growth with greater estrogenic activity than the current standard, tamoxifen. ${ }^{109,110}$ The developers of idoxifene tried to minimize the negative side effects of tamoxifen by substituting the dimethylamino group found on tamoxifen with a pyrrolidino group to avoid the production of a desmethyl metabolite and formaldehyde after metabolism in the liver. ${ }^{11}$ The second 
structural difference in idoxifene was the addition of an iodine at the 4 th position to reduce the estrogenic activity in addition to inhibiting glucoronidation and 4-hydroxylation allowing for a longer duration of action. ${ }^{112,113}$ In initial trials and testing, the modifications were very successful, as idoxifene was found to have a $2.5 \times$ slower rate of metabolism compared to tamoxifen which resulted in a terminal half-life that was about double that of tamoxifen. ${ }^{114}$ The peak plasma level was achieved after 2-8 hours post administration, and the drug had linear pharmacokinetics. The slower metabolism and longer half-life gave idoxifene a steady state concentration that was $50 \%$ higher than that of tamoxifen. Elimination of the drug was in a biphasic manner with linear kinetics over the dose range tested $(10-60 \mathrm{mg}) .{ }^{111}$

Functionally, idoxifene was determined to work through the estrogen response element. ${ }^{115}$ Compared to its parent drug, tamoxifen, idoxifene displayed 2-2.5× greater affinity for the $\mathrm{ER} \alpha$ receptor $^{110,112}$ and displayed desired effects in breast, bone, uterus, and endometrium. ${ }^{115-117}$ In breast tissue, idoxifene was found to have similar effects to that of tamoxifen indicating that it acted as an ER $\alpha$ antagonist. ${ }^{117}$ In MCF-7 cells, idoxifene was $1.5 \times$ more effective in inhibiting estrogen dependent cell growth compared to tamoxifen. On a gross level, idoxifene caused overall reduction in tumor size which indicated efficacy in breast cancer. ${ }^{117}$ In the endometrium and uterus, idoxifene was determined to have limited agonistic activity and blocked gene expression in endometrial cells, possibly indicating antagonistic behavior. ${ }^{116}$ This low level of activity in the uterus is lower than that of tamoxifen and was shown to decrease the risk of uterine cancer development posttreatment, which is typically elevated in tamoxifen, posttherapy. ${ }^{112}$ In bone, idoxifene functioned as an ER agonist, acting in a similar way to endogenous estrogen in that it promoted the activity of osteoblasts while promoting apoptosis of osteoclasts. ${ }^{115,116}$ The effects of idoxifene on bone included a suppression of urinary pyridium cross link expression and a serum osteocalcin level increase that is typically seen in estrogen withdrawal-based bone turn over. In addition, alkaline phosphatase levels were increased, suggesting increased bone formation. ${ }^{116}$ The combinations of these promising results led to a Phase I trial for idoxifene. This trial, conducted by Coombes et al treated 14 patients with idoxifene who had previously received tamoxifen therapy and showed that four of the 14 had tumor stabilization for $14,8,8$, and 1.5 months, while two of the 14 showed a partial response to the new drug. ${ }^{111}$ Endocrine changes for idoxifene were identical to tamoxifen for the luteinizing hormone (LH) and follicle stimulating hormone (FSH), in that patients saw a decrease in both. However, in contrast to tamoxifen, there was no change in sex hormone binding globulin (SHBG) when the patients were treated with idoxifene. This suggested a slightly different mechanism for idoxifene compared to its parent tamoxifen, as tamoxifen typically causes an increase in SHBG. This study proved promising which led to Phase II trials for idoxifene.

In Phase II trials for idoxifene, clinical data showed that of the 25 patients who received idoxifene, two had a partial response (PR) and two had steady disease for greater than 6 months. The PR duration was for 30 months and 5 months. In the patients who had steady disease, they had demonstrated resistance, as they had a PR or complete response to tamoxifen in prior treatments 2 and 7 years prior. In addition, in the Phase II trial, the endocrine changes were identical to that of tamoxifen, suggesting that the Phase I trial was underpowered. The clinical data for idoxifene proved to be not significantly different than tamoxifen, but the drug was further tested in Phase III trials. ${ }^{118}$

During Phase III trials for idoxifene, it was determined that patient outcomes for idoxifene were not significantly different than those for tamoxifen. Complete response, PR, and steady disease groups were not significantly different and neither was long-term survival. Due to these findings, Phase III enrollment was cut before the study was completed by the sponsor, SmithKline Beecham, due to limited potential for profit. Some of the side effects reported during the study included nausea, anorexia, vomiting, increased urinary incontinence, increased risk of pelvic organ prolapse, increased endometrial thickness, and increased risk of leucorrhea. ${ }^{19,120}$ It is important to note that deaths due to treatment were not significantly different in treatment with either idoxifene and tamoxifen, indicating that idoxifene is a safe but not significantly safer treatment option than tamoxifen. ${ }^{120}$

\section{Benzothiophene SERMs Raloxifene}

A second generation SERM (formally called keoxifene) is a chemically distinct polyhydroxy phenol benzothiophene series SERM that has different tissue-specific effects compared to tamoxifen. Raloxifene was first developed for breast cancer therapy, however it was determined that raloxifene did not have activity in tamoxifen resistant breast cancer patients. It soon became apparent that raloxifene may prevent bone loss and prevent breast cancer, which led to clinical trials and eventually raloxifene became the first SERM to be approved by the Food and Drug Administration for the treatment and prevention of postmenopausal osteoporosis..$^{97,121-124}$ Although 
the exact mechanism of raloxifene's effects has yet to be determined, its metabolism is not reported to proceed through the P450 pathway like tamoxifen.

Raloxifene is extensively metabolized though glucuronidation pathways and may proceed through oxidation by the liver to electrophilic diquinone methide and o-quinones. ${ }^{125}$ Although both of these metabolites may potentially be destructive, either their short half-life or stable minor production decreases their clinical toxicity.

Raloxifene is mostly known for its therapeutic use in osteoporosis, and while it failed as a breast cancer treatment, it is still effective at preventing breast cancer. ${ }^{49}$ Raloxifene's effectiveness as a long-term therapeutic for reducing the occurrence of invasive breast cancer was examined in the MORE trial (multiple outcomes of raloxifene evaluation) where it was determined that it reduced the incidence of osteoporosis and breast cancer in postmenopausal women. ${ }^{126,127}$ Furthermore, unlike tamoxifen, raloxifene is not associated with, and may even be effective at, preventing endometrial cancer. ${ }^{127,128}$ The realization that raloxifene has fewer estrogen-like effects than tamoxifen in laboratory rats resulted in a clinical trial to compare tamoxifen and raloxifene's efficacy as a breast cancer preventive and their effect in the uterus. In the Study of Tamoxifen and Raloxifene (STAR) trial, a Phase II, randomized double-blind evaluation of the efficacy of raloxifene ( $60 \mathrm{mg}$ oral) compared to tamoxifen (20 mg oral), it was determined that tamoxifen and raloxifene are equally effective at preventing breast cancer progression over a 5-year period. Furthermore, in 81 months, raloxifene is $75 \%$ as effective as tamoxifen, and there were less thromboembolic events and fewer cataracts in the raloxifene group. ${ }^{62}$ In trials assessing raloxifene's effect on the endometrium, it has been determined that, compared to placebo, there was no difference, and compared to tamoxifen, raloxifene reduced the incidence of endometrial cancer. ${ }^{62,129}$ The observation that raloxifene does not increase the incidence of endometrial cancer, may be a result of its inability to stimulate the co-activator protein SRC1 in both uterine cells and breast cancer cell lines. ${ }^{72}$ Raloxifene also has no effect on vaginal lubrication, ${ }^{130}$ and similar to tamoxifen, raloxifene is associated with an increase in hot flashes, an increased risk of blood clots, and resistance. ${ }^{29}$

\section{Arzoxifene}

Arzoxifene is a third generation SERM that is a roloxifene analogue with the replacement of the carbonyl functional group with an ether linkage and the addition of a methyl group to the $4^{\prime}$ phenolic hydroxyl group. ${ }^{131,132}$ After raloxifene failed to show effects as a therapeutic in metastatic breast cancer, arzoxifene was developed to show that benzothiophenes were still a viable drug option in the treatment of breast cancer. During initial trials, it showed promise as being the "ideal SERM." However, during late Phase II testing and Phase III trials, it was proven to be less effective than tamoxifen, destroying its efforts to be used as a breast cancer therapeutic. ${ }^{133}$ Arzoxifene uses a raloxifene base and then replaces the carbonyl group found on raloxifene with oxygen which results in a substantial increase in estrogen antagonistic potency compared to raloxifene. By doing this, bioavailability was also increased. ${ }^{134,135}$ Supporting this was the 10-fold improvement in IC50 values from raloxifene to arzoxifene. ${ }^{134}$ Arzoxifene is metabolized by the P450 system to produce its active metabolite, desmethylarzoxifene, which has $8 \times$ greater affinity for $\mathrm{ER} \alpha$ than arzoxifene and approximately $24 \times$ greater affinity for ER $\alpha$ than the active metabolite of tamoxifen, 4-OHT ligand. ${ }^{135-137}$ Additionally, like raloxifene, desmethylarzoxifene can be further oxidized to diquinone methide. ${ }^{138-140}$

The primary goal for the development of arzoxifene was for it to be used for metastatic breast cancer. In initial studies, it was shown that arzoxifene caused inhibition of growth in breast epithelial cells while also inhibiting the growth of basal cells in the absence of estrogen. This differed from tamoxifen, which inhibited the growth of epithelial cells and caused the stimulation of basal cell proliferation. ${ }^{135}$ In addition to its effect in breast cancers, arzoxifene also inhibited the agonistic effects of estrogen in the uterus and on endometrial cell growth. ${ }^{134,135}$ The combinations of these effects led to the exploration of arzoxifene in Phase I trials. In a Phase I trial of 32 women with metastatic breast cancer (all of which had received prior hormone therapy or chemotherapy), arzoxifene was given. None of the women saw an objective response and 19\% had steady disease for greater than 6 months (6-34 months; median 7.7 months). ${ }^{141}$ It also proved itself to be as effective as estrogen in anti-absorptive effects on bone in postmenopausal women. Like tamoxifen, arzoxifene was found to decrease FSH and LH levels and increase SHBG. ${ }^{133}$ In addition, during other Phase I trials, it was found that arzoxifene caused decreases in proliferating cell nuclear antigen, IGF-1, and IGF binding protein 3. ${ }^{142}$ Though no objective response was seen, the hormonal data and results on endometrium prompted Phase II trials. In these trials, results showed that lower doses (20 mg versus $50 \mathrm{mg}$ ) of arzoxifene showed better objective response rates, with hormone panels for FSH, LH, and SHBG confirming Phase I results. ${ }^{143}$ With regards to bone mineral density (BMD), the 
study for Phase II was underpowered so there were not enough premenopausal women enrolled to make reliable inferences. ${ }^{144}$ Initial reports of the drug showed possible efficacy in endometrial cancer treatment. During Phase II trials, the drug was given to 34 patients and overall response rate was reported to be $31 \%$ (one complete response and eight PR). Results were comparable or better than previous treatments with progesterone with or without tamoxifen. In spite of supportive results, the drug was not pursued further by the manufacturer. ${ }^{141}$

Though the drug was pulled after Phase II trials, some Phase III trials had begun and showed the drug had efficacy in the treatment of breast cancer. However, when compared head to head with tamoxifen, the results were disappointing. Tamoxifen proved superior in progression-free survival, time to treatment failure, and on study progression-free survival. However, it is important to note that there were no significant differences in overall response rate, clinical benefit rate, median response duration, or overall survival. ${ }^{141}$ The major side effects reported throughout the trials included hot flashes (non-dose dependent), nausea, cutaneous side effects, neuromotor toxicity, and weight gain. ${ }^{133,141}$ However, as stated earlier, the drug was not pursued further by the manufacturer in the treatment of breast cancer. There still remains potential for this drug in the treatment of uterine cancers and postmenopausal bone density loss.

\section{Indole, tetrahydronaphthalene, and naphthol SERMs Lasofoxifene}

Lasofoxifene, similar to other SERMs, selectively binds human ER $\alpha$ and ER $\beta$ with an affinity similar to estradiol. ${ }^{145-147}$ This SERM has been shown to function as a skeletal agonist and a breast and uterine antagonist. ${ }^{44,148-152}$ Lasofoxifene's structure is similar to that of endogenous estrogens, with a polyaromatic phenol scaffold that may be oxidized to catechols ${ }^{153}$ which may cause toxicity. Lasofoxifene is a third generation nonsteroidal SERM with a similar structure to idoxifene. The osteoporosis prevention and lipid lowering and Postmenopausal Evaluation and Risk Reduction with Lasofoxifene (PEARL) studies were aimed at evaluating the efficacy of lasofoxifene use in the treatment of osteoporosis. The results of the osteoporosis prevention and lipid lowering, which assessed vaginal and bone effect of lasofoxifene in non-osteoporotic women, indicated that changes in BMD were significantly reduced in the lasofoxifene group compared to placebo. It was also determined that there was an improvement in vaginal $\mathrm{pH}$ after 2 years of therapy. ${ }^{154}$ The
PEARL trials showed that in postmenopausal women with low bone density, lasofoxifene therapy was associated with reductions in all breast cancer (79\%) and ER-positive breast cancer $(81 \%)$, as well as the reduction in non-vertebral $(24 \%)$ and vertebral fractures (42\%), coronary heart disease (32\%), and stroke (36\%) compared to placebo. ${ }^{155}$ Furthermore, the Comparison of Raloxifene and Lasofoxifene (CORAL) trial compared the effects of lasofoxifene, raloxifene, and placebo on BMD in postmenopausal women and found that after 2 years of treatment, lasofoxifene was associated with an improved lumbar spine BMD and reduced low-density lipoprotein cholesterol levels compared to placebo. ${ }^{151}$ In rat models, lasofoxifene, like most SERMs (including tamoxifen), also acted as an estrogen agonist in serum cholesterol ${ }^{156}$ and had the effect of reducing total serum cholesterol and low-density lipoproteins. This suggests that there may be potential cardiovascular advantages associated with the treatment of osteoporosis with SERMs. Compared to placebo, lasofoxifene was associated with leg cramps, hot flashes, endometrial hypertrophy, uterine polyps, and vaginal candidiasis. ${ }^{155}$ Furthermore, in rat models, lasofoxifene has no effect in the prostate. ${ }^{145}$ The absence of effect in the prostate indicates that lasofoxifene may also be a useful therapeutic for men with some degree of hypogonadism.

\section{Bazedoxifene}

Bazedoxifene is a third generation SERM created as an indole-based ER ligand that was specifically designed to prevent and treat postmenopausal osteoporosis with reduced negative effects compared to previous SERMs, and can be given with conjugated equine estrogens for menopausal symptoms. ${ }^{157}$ Bazedoxifene design differed from its predecessors in its core binding domain, which consists of a 2-phenyl-3-methyl indole, a side chain effector region connected to the core binding region via a methylene hinge, and a hexamethylenediamine ring at the side chain terminus. ${ }^{44}$ Part of bazedoxifene's design was to prevent effects on the uterus such as those seen with levormeloxifene, idoxifene, and droloxifene. Bazedoxifene's binding affinity is slightly higher for ER $\alpha$ compared to ER $\beta .^{158,159}$ The metabolism of bazedoxifene involves P450 glucuronidation at the indole 5 and $4^{\prime}$ hydroxyl positions. ${ }^{160}$

In general, bazedoxifene's estrogenic effects are agonist in bone and lipid metabolism and antagonistic in breast and endometrium. ${ }^{44,161,162}$ Bazedoxifene acetate is effective in preventing and treating osteoporosis, and improving lipid profile. ${ }^{44}$ A 2-year, double blind study designed to assess the effects of bazedoxifene on BMD determined that BMD was 
improved at all skeletal sites compared to placebo, which was similar to a $60 \mathrm{mg}$ raloxifene (positive control) treatment. Furthermore, the incidence of new vertebral fractures was significantly lower in the bazedoxifene group compared to placebo. There was no difference in the incidence of vertebral fractures or breast or endometrial carcinoma between treatment groups. ${ }^{163-165}$ The SMART-1 trial investigated the use of bazedoxifene and conjugated estrogens compared to placebo on the effects of endometrial lining and BMD. The results indicated that the bazedoxifene plus conjugated estrogens group had reduced incidence of endometrial hyperplasia over placebo at 2 years and a significantly increased BMD in the lumbar spine and hip. ${ }^{166,167}$ In a separate 5-year international, double blind, randomized, trial $(n=7,492)$ it was determined that bazedoxifene reduced the risk of new vertebral fractures at both a dose of $10 \mathrm{mg}$ and $40 \mathrm{mg}$ compared to raloxifene $(60 \mathrm{mg})$ and placebo. Additionally, the risk of non-vertebral fracture risk was reduced by $44 \%$ with bazedoxifene ( $20 \mathrm{mg}$ ) compared to raloxifene. In the same sample, it was determined that bazedoxifene $(20 \mathrm{mg}$ ) decreased the risk of new vertebral fracture by $50 \%$ in those who were at a higher fracture risk or had a previous vertebral fracture $(n=1,771) .{ }^{163}$ The most common adverse effects observed with bazedoxifene use are hot flashes and leg cramps, and the rates of endometrial hyperplasia, cancer, and polyps were low in these trials. The most serious negative effect was an increased risk of venous thromboembolism. ${ }^{163,168,169}$ Furthermore, transvaginal ultrasonography and mammography were administered to a subset $(n=753)$ of patients taking bazedoxifene, raloxifene, and placebo in order to assess endometrial safety and breast density. The results showed that there was no between group differences in mean endometrial thickness or change from baseline in endometrial thickness associated with the use of either bazedoxifene or raloxifene. ${ }^{168,170}$ This finding was supported by a randomized, double blind, placebo and active controlled study that found that bazedoxifene had no activity on endometrial or breast tissue. ${ }^{171}$

\section{LY20266948}

The goal in the development of LY2066948 was to develop the ideal SERM that did not have the toxic effects of tamoxifen or its other derivatives. The ligand binds both $\mathrm{ER} \alpha$ and $\mathrm{ER} \beta$ with high affinity $\mathrm{Ki} 0.51 \mathrm{~nm}$ and $1.36 \mathrm{~nm}$, respectively. ${ }^{172}$ LY2066948 shows potent uterine antagonistic effects. ${ }^{173}$ This was demonstrated through both in vitro and in vivo studies. In in vivo studies following treatment with estrogen in immature female rats ( 3 weeks), a significant $(3-4 \times)$ increase in uterine weight was seen. Treatment with
LY2066948 showed significant inhibitory effects on the estrogen stimulated uterine growth at a dose of $10 \mathrm{mg} / \mathrm{kg} .{ }^{173}$ The ED50 value for LY2066948 was determined to be $0.07+$ $-0.02 \mathrm{mg} / \mathrm{kg}{ }^{172} \mathrm{With}$ estrogen stimulus, potency compares well with tamoxifen and raloxifene. ${ }^{134}$ Additionally, overall results show no significant ovarian stimulation. ${ }^{172}$ In vitro studies of LY2066948 in uterine tissues showed 87.5\% inhibition of E2 stimulated response at $1 \mathrm{nM}$ and IC50 of $10.7 \mathrm{nM}$. The IC50 of tamoxifen was $421 \mathrm{~nm}$ with only $53.4 \%$ inhibition. ${ }^{172}$ LY2066948 is similar in structure to raloxifene, and undergoes metabolism through the P-450 pathway in the liver. This metabolism leads to the eventual formation of the metabolite 3,4-o-quinone ${ }^{174,175}$ and, based on its structure, this metabolite is not as toxic as those produced by other SERMs. ${ }^{176}$

\section{Tamoxifen versus raloxifene}

Raloxifene is used to reduce the risk of breast cancer in postmenopausal women with osteoporosis, and both tamoxifen and raloxifene are used to decrease the risk of breast cancer in high-risk women. In general, raloxifene has less estrogen-like effects compared to tamoxifen. The most notable distinction between these two drugs is that raloxifene does not share the pro-estrogenic effects of tamoxifen on the endometrium, which corresponds to an increased risk of endometrial cancer. ${ }^{128}$ A potential mechanism for the difference in actions of these drugs is based on differential actions within the ligand binding domain (AF-2 domain) of $E R \alpha . E R \alpha$ has an amino acid Asp-351 present within the ligand binding domain whose relationship to the antiestrogenic side chain and the AF-2 site profoundly affects the nature of the estrogen-like outcome. In the case of raloxifene, removing the neutralizing change of the piperidine by substituting a cyclohexane resulted in increased estrogenlike actions, and moving the side chain of 4-OHT further away from Asp-351 also resulted in enhanced estrogen-like activity. ${ }^{177,178}$ Similarly, the effect of raloxifene is altered by changing the distance between the piperidine nitrogen and the negatively charged amino acid Asp-351. It is believed that the sidechain of raloxifene shields and neutralizes the Asp-351 to produce an anti-estrogenic ER $\alpha$ complex within the uterus. ${ }^{178}$

\section{Tamoxifen toxicity}

Tamoxifen and TOR are both nonsteroidal triphenylethylene derivatives, differing only in the substitution of a chloride atom for hydrogen in an ethyl chain of TOR.${ }^{85}$ One major difference between the two drugs is that tamoxifen is associated 
with an increased risk of endometrial cancer, and TOR has less genotoxic potential and may not have an association with endometrial cancer. Endogenous estrogen alone is known to be an endometrial carcinogenic, ${ }^{84}$ and tamoxifen is a partial agonist of estrogen in endometrial tissue. However, estrogen-like activity is unlikely to be the only mechanism resulting in tamoxifen's effects on the endometrium since the tumors caused by endogenous estrogens are usually low stage and grade, ${ }^{179}$ and tamoxifen associated tumors are more aggressive. ${ }^{180,181}$

The increased incidence of endometrial cancer observed during tamoxifen administration are believed to be due to the formation of major DNA adducts primarily formed via sulfonation of $\alpha$-hydroxylated tamoxifen metabolites such as $\alpha$-OHTAM and hydroxyl-N-desmethyltamoxifen. ${ }^{81,91,182-184}$ As previously noted, tamoxifen's activity is dependent on its metabolism by P-450 enzymes within the liver. Endogenous estrogens, which are also known as carcinogens, are also metabolized to form 2, and 4-hydroxy catechols. ${ }^{185}$ It is believed that estrogens 4-hydroxy catechol metabolites display the most genotoxicity due to o-quinones', a 4-hydroxy catechol metabolite, ability to react with DNA to form genotoxic DNA adducts. ${ }^{185}$ Metabolism of tamoxifen produces reactive carbocation, o-quinone, and quinone methide intermediates. ${ }^{186-189}$ It appears that these metabolites have the potential to form genotoxic DNA adducts.

These DNA adducts generate primarily guanine-to-thymine transversions in mammalian cells that have a large mutagenic potential and have been detected in the endometrium of women treated with tamoxifen. ${ }^{190-193}$ If not repaired, these adducts may cause mutations that can lead to endometrial cancer. ${ }^{194}$ Conversely, TOR lacks the DNA adduct-forming ability and the genotoxicity of tamoxifen and has not been associated with the increased risk of endometrial cancer. ${ }^{91-95}$ Similarly, tamoxifen has been confirmed to function as a potent hepatocarcinogen, which may be a result of its DNA adduct-forming ability, and the lack of hepatocarcinogen ability of TOR may again result from its inability to form DNA adducts. ${ }^{85}$ Supporting genotoxicity and hepatocarcinogenesis associated with tamoxifen, it was determined that tamoxifen increases point mutations and deletion mutation in the liver of gpt delta rats, and this effect was not found with TOR administration. ${ }^{195}$ Both tamoxifen and 4-OHT can be metabolized by P450 to 3,4,dihydroxytamoxifen that can proceed to o-quinones via oxidation, and this metabolite was determined to have an extended half-life and the potential to cause genotoxicity, and may cause alkylation of amino acid residues on proteins. ${ }^{196}$ Another potentially more carcinogenic metabolite of tamoxifen are the carbocations, which are produced from sulfonation, and the subsequent loss of a sulfate group following hydroxylation of tamoxifen by $\mathrm{P} 450$ at the $\alpha$-position. ${ }^{188}$ This creates a highly reactive electrophilic carbocation that has a high affinity for binding the exocyclic amino group of quinine in DNA, leading to DNA adduct formation and potentially, mutagenesis. ${ }^{197}$ Lastly, quinone methides, which differ from quinones due to a methylene group replacing the carbonyl oxygen, are formed following a two-electron oxidation of 4-OHT. ${ }^{174,187}$ It appears that quinone methides have the ability to form benzylic adducts of macromolecules and therefore may contribute to DNA adduct formation, ${ }^{198,199}$ although their extent of involvement has not been determined.

\section{Metabolites of the benzothiophene SERMs}

Raloxifene is extensively metabolized though glucuronidation pathways, and may proceed through oxidation by the liver to electrophilic diquinone methide and o-quinones. ${ }^{125}$ Diquinone methide, which is also a metabolite of arzoxifene, is an electrophilic, active intermediate that may be a P450 $3 \mathrm{~A} 4$ inhibitor in human liver microsomes and may result in adduct formation with apoprotein. ${ }^{138-140}$ However, the halflife of diquinone methide is less than 1 second, suggesting that it does not significantly contribute to the toxicity profile of raloxifene. The other metabolite of raloxifene, a relatively stable o-quinone, is a known toxin; however, it is the minor product of raloxifene metabolism. ${ }^{125}$

\section{Conclusion}

ER ligands have historically been classified by their actions, either as an agonist or an antagonist, but in reality, it appears that each falls somewhere within a continuum of agonist and antagonist and is dependent on multiple aspects of each tissue and drug. The ideal SERM would regulate menopausal symptoms, protect the skeleton, and prevent breast cancer without the negative effects associated with hormone therapy.

\section{Disclosure}

The authors report no conflicts of interest and have nothing to disclose.

\section{References}

1. Jaffe AB, Toran-Allerand CD, Greengard P, Gandy SE. Estrogen regulates metabolism of Alzheimer amyloid beta precursor protein. $J$ Biol Chem. 1994;269(18):13065-13068

2. Resnick SM, Maki PM, Golski S, Kraut MA, Zonderman AB. Effects of estrogen replacement therapy on PET cerebral blood flow and neuropsychological performance. Horm Behav. 1998;34(2):171-182. 
3. Komm BS. A new approach to menopausal therapy: the tissue selective estrogen complex. Reprod Sci. 2008;15(10):984-992.

4. Berrodin TJ, Chang KC, Komm BS, Freedman LP, Nagpal S. Differential biochemical and cellular actions of Premarin estrogens: distinct pharmacology of bazedoxifene-conjugated estrogens combination. Mol Endocrinol. 2009;23(1):74-85.

5. Kharode Y, Bodine PV, Miller CP, Lyttle CR, Komm BS. The pairing of a selective estrogen receptor modulator, bazedoxifene, with conjugated estrogens as a new paradigm for the treatment of menopausal symptoms and osteoporosis prevention. Endocrinology. 2008;149(12):6084-6091.

6. Riggs BL, Hartmann LC. Selective estrogen-receptor modulators mechanisms of action and application to clinical practice. $N$ Engl J Med. 2003;348(7):618-629.

7. Goldstein SR. Not all SERMs are created equal. Menopause. 2006;13(3):325-327.

8. Enmark E, Pelto-Huikko M, Grandien K, et al. Human estrogen receptor beta-gene structure, chromosomal localization, and expression pattern. J Clin Endocrinol Metab. 1997;82(12):4258-4265.

9. Katzenellenbogen BS, Korach KS. A new actor in the estrogen receptor drama - enter ER-beta. Endocrinology. 1997;138(3):861-862.

10. Kuiper GG, Carlsson B, Grandien K, et al. Comparison of the ligand binding specificity and transcript tissue distribution of estrogen receptors alpha and beta. Endocrinology. 1997;138(3):863-870.

11. Kuiper GG, Enmark E, Pelto-Huikko M, Nilsson S, Gustafsson JA. Cloning of a novel receptor expressed in rat prostate and ovary. Proc Natl Acad Sci U S A. 1996;93(12):5925-5930.

12. Mosselman S, Polman J, Dijkema R. ER beta: identification and characterization of a novel human estrogen receptor. FEBS Lett. 1996;392(1):49-53.

13. Somjen D, Katzburg S, Sharon O, Grafi-Cohen M, Knoll E, Stern N. The effects of estrogen receptors $\alpha$ - and $\beta$-specific agonists and antagonists on cell proliferation and energy metabolism in human bone cell line. J Cell BiochemI. 2011;112(2):625-632.

14. Zhang B, Wu ZY. Estrogen derivatives: novel therapeutic agents for liver cirrhosis and portal hypertension. Eur J Gastroenterol Hepatol. 2013;25(3):263-270.

15. Rossi V, Bellastella G, De Rosa C, et al. Raloxifene induces cell death and inhibits proliferation through multiple signaling pathways in prostate cancer cells expressing different levels of estrogen receptor $\alpha$ and B. Journal Cell Physiol. 2011;226(5):1334-1339.

16. Helguero LA, Faulds MH, Gustafsson JA, Haldosen LA. Estrogen receptors alfa (ERalpha) and beta (ERbeta) differentially regulate proliferation and apoptosis of the normal murine mammary epithelial cell line HC11. Oncogene. 2005;24(44):6605-6616.

17. Wada-Hiraike O, Imamov O, Hiraike $\mathrm{H}$, et al. Role of estrogen receptor beta in colonic epithelium. Proc Natl Acad Sci U S A. 2006; 103(8):2959-2964.

18. Wada-Hiraike O, Hiraike $\mathrm{H}$, Okinaga $\mathrm{H}$, et al. Role of estrogen receptor beta in uterine stroma and epithelium: Insights from estrogen receptor beta-/- mice. Proc Natl Acad Sci U S A. 2006;103(48):18350-18355.

19. Clark JA, Alves S, Gundlah C, et al. Selective estrogen receptor-beta (SERM-beta) compounds modulate raphe nuclei tryptophan hydroxylase-1 (TPH-1) mRNA expression and cause antidepressant-like effects in the forced swim test. Neuropharmacology. 2012;63(6):1051-1063.

20. Sotoca AM, van den Berg H, Vervoort J, et al. Influence of cellular ERalpha/ERbeta ratio on the ERalpha-agonist induced proliferation of human T47D breast cancer cells. Toxicol Sci. 2008;105(2):303-311.

21. Krege JH, Hodgin JB, Couse JF, et al. Generation and reproductive phenotypes of mice lacking estrogen receptor beta. Proc Natl Acad Sci U S A. 1998;95(26):15677-15682.

22. Taylor AH, Al-Azzawi F. Immunolocalisation of oestrogen receptor beta in human tissues. $J$ Mol Endocrinol. 2000;24(1):145-155.

23. Warner M, Nilsson S, Gustafsson JA. The estrogen receptor family. Curr Opin Obstet Gynecol. 1999;11(3):249-254.

24. Nilsson S, Gustafsson JA. Estrogen receptors: therapies targeted to receptor subtypes. Clin Pharmacol Ther. 2011;89(1):44-55.
25. Nilsson S, Koehler KF, Gustafsson JA. Development of subtypeselective oestrogen receptor-based therapeutics. Nat Rev Drug Discov. 2011;10(10):778-792.

26. Nilsson S, Mäkelä S, Treuter E, et al. Mechanisms of estrogen action. Physiol Rev. 2001;81(4):1535-1565.

27. Anstead GM, Carlson KE, Katzenellenbogen JA. The estradiol pharmacophore: ligand structure-estrogen receptor binding affinity relationships and a model for the receptor binding site. Steroids. 1997;62(3):268-303.

28. Beato M, Sanchez-Pacheco A. Interaction of steroid hormone receptors with the transcription initiation complex. Endocr Rev. 1996;17(6):587-609.

29. Jordan VC. Selective estrogen receptor modulation: concept and consequences in cancer. Cancer Cell. 2004;5(3):207-213.

30. McDonnell DP. The Molecular Pharmacology of SERMs. Trends Endocrinol Metab. 1999;10(8):301-311.

31. Arnal JF, Fontaine C, Abot A, et al. Lessons from the dissection of the activation functions (AF-1 and AF-2) of the estrogen receptor alpha in vivo. Steroids. 2013;78(6):576-582.

32. Beato M, Herrlich P, Schütz G. Steroid hormone receptors: many actors in search of a plot. Cell. 1995;83(6):851-857.

33. Planey SL, Kumar R, Arnott JA. Post-translational modification of transcription factors: mechanisms and potential therapeutic interventions. Curr Mol Pharmacol. 2013;6(3):173-182.

34. Beato M. Gene regulation by steroid hormones. Cell. 1989;56(3): 335-344.

35. Tora L, White J, Brou C, et al. The human estrogen receptor has two independent nonacidic transcriptional activation functions. Cell. 1989;59(3):477-487.

36. Berry M, Metzger D, Chambon P. Role of the two activating domains of the oestrogen receptor in the cell-type and promoter-context dependent agonistic activity of the anti-oestrogen 4-hydroxytamoxifen. EMBOJ. 1990;9(9):2811-2818.

37. Montano MM, Müller V, Trobaugh A, Katzenellenbogen BS. The carboxy-terminal $\mathrm{F}$ domain of the human estrogen receptor: role in the transcriptional activity of the receptor and the effectiveness of antiestrogens as estrogen antagonists. Mol Endocrinol. $1995 ; 9(7): 814-825$.

38. Koide A, Zhao C, Naganuma M, et al. Identification of regions within the $\mathrm{F}$ domain of the human estrogen receptor alpha that are important for modulating transactivation and protein-protein interactions. Mol Endocrinol. 2007;21(4):829-842.

39. Yang J, Singleton DW, Shaughnessy EA, Khan SA. The F-domain of estrogen receptor-alpha inhibits ligand induced receptor dimerization. Mol Cell Endocrinol. 2008;295(1-2):94-100.

40. Smith CL, O'Malley BW. Coregulator function: a key to understanding tissue specificity of selective receptor modulators. Endocr Rev. 2004;25(1):45-71.

41. Ascenzi P, Bocedi A, Marino M. Structure-function relationship of estrogen receptor alpha and beta: impact on human health. Mol Aspects Med. 2006;27(4):299-402.

42. Edwards DP. Regulation of signal transduction pathways by estrogen and progesterone. Annu Rev Physiol. 2005;67:335-376.

43. McKenna NJ, O'Malley BW. Combinatorial control of gene expression by nuclear receptors and coregulators. Cell. 2002;108(4): 465-474.

44. Komm BS, Kharode YP, Bodine PV, Harris HA, Miller CP, Lyttle CR. Bazedoxifene acetate: a selective estrogen receptor modulator with improved selectivity. Endocrinology. 2005;146(9):3999-4008.

45. Pike AC, Brzozowski AM, Hubbard RE, et al. Structure of the ligandbinding domain of oestrogen receptor beta in the presence of a partial agonist and a full antagonist. EMBO J. 1999;18(17):4608-4618.

46. Shiau AK, Barstad D, Loria PM, et al. The structural basis of estrogen receptor/coactivator recognition and the antagonism of this interaction by tamoxifen. Cell. 1998;95(7):927-937.

47. Shanle EK, Xu W. Selectively targeting estrogen receptors for cancer treatment. Adv Drug Deliv Rev. 2010;62(13):1265-1276. 
48. Lonard DM, O'Malley BW. Nuclear receptor coregulators: judges, juries, and executioners of cellular regulation. Mol Cell. 2007;27(5):691-700.

49. Peng J, Sengupta S, Jordan VC. Potential of selective estrogen receptor modulators as treatments and preventives of breast cancer. Anticancer Agents Med Chem. 2009;9(5):481-499.

50. Métivier R, Penot G, Hübner MR, et al. Estrogen receptor-alpha directs ordered, cyclical, and combinatorial recruitment of cofactors on a natural target promoter. Cell. 2003;115(6):751-763.

51. Funakoshi T, Yanai A, Shinoda K, Kawano MM, Mizukami Y. G proteincoupled receptor 30 is an estrogen receptor in the plasma membrane. Biochemical and Biophys Res Commun. 2006;346(3):904-910.

52. Filardo EJ, Quinn JA, Sabo E. Association of the membrane estrogen receptor, GPR30, with breast tumor metastasis and transactivation of the epidermal growth factor receptor. Steroids. 2008;73(9-10):870-873.

53. Lonard DM, O'Malley BW. The expanding cosmos of nuclear receptor coactivators. Cell. 2006;125(3):411-414.

54. Pace P, Taylor J, Suntharalingam S, Coombes RC, Ali S. Human estrogen receptor beta binds DNA in a manner similar to and dimerizes with estrogen receptor alpha. J Biol Chem. 1997;272(41):25832-25838.

55. Cowley SM, Hoare S, Mosselman S, Parker MG. Estrogen receptors alpha and beta form heterodimers on DNA. J Biol Chem. 1997;272(32):19858-19862.

56. Charn TH, Liu ET, Chang EC, Lee YK, Katzenellenbogen JA, Katzenellenbogen BS. Genome-wide dynamics of chromatin binding of estrogen receptors alpha and beta: mutual restriction and competitive site selection. Mol Endocrinol. 2010;24(1):47-59.

57. Schultz JR, Loven MA, Melvin VM, Edwards DP, Nardulli AM. Differential modulation of DNA conformation by estrogen receptors alpha and beta. $J$ Biol Chem. 2002;277(10):8702-8707.

58. Paulmurugan R, Tamrazi A, Massoud TF, Katzenellenbogen JA, Gambhir SS. In vitro and in vivo molecular imaging of estrogen receptor $\alpha$ and $\beta$ homo- and heterodimerization: exploration of new modes of receptor regulation. Mol Endocrinol. 2011;25(12):2029-2040.

59. Veronesi U, Boyle P, Goldhirsch A, Orecchia R, Viale G. Breast cancer. Lancet. 2005;365(9472):1727-1741.

60. Jordan VC. Tamoxifen: a most unlikely pioneering medicine. Nat Rev Drug Discov. 2003;2(3):205-213.

61. Gottardis MM, Ricchio ME, Satyaswaroop PG, Jordan VC. Effect of steroidal and nonsteroidal antiestrogens on the growth of a tamoxifenstimulated human endometrial carcinoma (EnCa101) in athymic mice. Cancer Res. 1990;50(11):3189-3192.

62. Vogel VG, Costantino JP, Wickerham DL, et al. Effects of tamoxifen vs raloxifene on the risk of developing invasive breast cancer and other disease outcomes: the NSABP Study of Tamoxifen and Raloxifene (STAR) P-2 trial. JAMA. 2006;295(23):2727-2741.

63. Early Breast Cancer Trialists' Collaborative Group (EBCTCG); Davies C, Godwin J, Gray R, et al. Relevance of breast cancer hormone receptors and other factors to the efficacy of adjuvant tamoxifen: patient-level meta-analysis of randomised trials. Lancet. 2011;378(9793):771-784.

64. den Hollander P, Savage MI, Brown PH. Targeted therapy for breast cancer prevention. Front Oncol. 2013;3:250.

65. Cuzick J, Powles T, Veronesi U, et al. Overview of the main outcomes in breast-cancer prevention trials. Lancet. 2003;361(9354):296-300.

66. Kontostolis E, Stefanidis K, Navrozoglou I, Lolis D. Comparison of Tamoxifen with danazol for treatment of cyclical mastalgia. Gynecol Endocrinol. 1997;11(6):393-397.

67. Oksa S, Luukkaala T, Mäenpää JU. Toremifene use does not alter serum inhibin A and B levels during mid-luteal phase in women with premenstrual mastalgia. Gynecol Endocrinol. 2010;26(2):114-117.

68. Kiyotani K, Mushiroda T, Nakamura Y, Zembutsu H. Pharmacogenomics of tamoxifen: roles of drug metabolizing enzymes and transporters. Drug Metab Pharmacokinet. 2012;27(1):122-131.

69. Lavinsky RM, Jepsen K, Heinzel T, et al. Diverse signaling pathways modulate nuclear receptor recruitment of N-CoR and SMRT complexes. Proc Natl Acad Sci U S A. 1998;95(6):2920-2925.
70. Jepsen K, Hermanson O, Onami TM, et al. Combinatorial roles of the nuclear receptor corepressor in transcription and development. Cell. 2000;102(6):753-763.

71. Keeton EK, Brown M. Cell cycle progression stimulated by tamoxifenbound estrogen receptor-alpha and promoter-specific effects in breast cancer cells deficient in N-CoR and SMRT. Mol Endocrinol. 2005;19(6):1543-1554.

72. Shang Y, Brown M. Molecular determinants for the tissue specificity of SERMs. Science. 2002;295(5564):2465-2468.

73. Liu XF, Bagchi MK. Recruitment of distinct chromatin-modifying complexes by tamoxifen-complexed estrogen receptor at natural target gene promoters in vivo. J Biol Chem. 2004;279(15):15050-15058.

74. Montano MM, Ekena K, Delage-Mourroux R, Chang W, Martini P, Katzenellenbogen BS. An estrogen receptor-selective coregulator that potentiates the effectiveness of antiestrogens and represses the activity of estrogens. Proc Natl Acad Sci U S A. 1999;96(12): 6947-6952.

75. Delage-Mourroux R, Martini PG, Choi I, Kraichely DM, Hoeksema J, Katzenellenbogen BS. Analysis of estrogen receptor interaction with a repressor of estrogen receptor activity (REA) and the regulation of estrogen receptor transcriptional activity by REA. J Biol Chem. 2000;275(46):35848-35856.

76. Fisher B, Costantino JP, Wickerham DL, et al. Tamoxifen for prevention of breast cancer: report of the National Surgical Adjuvant Breast and Bowel Project P-1 Study. J Natl Cancer Inst. 1998;90(18):1371-1388.

77. Spencer TE, Jenster G, Burcin MM, et al. Steroid receptor coactivator-1 is a histone acetyltransferase. Nature. 1997;389(6647):194-198.

78. Seoud MA, Johnson J, Weed JC Jr. Gynecologic tumors in tamoxifentreated women with breast cancer. Obstet Gynecol. 1993;82(2): 165-169.

79. Fisher B, Costantino JP, Redmond CK, Fisher ER, Wickerham DL, Cronin WM. Endometrial cancer in tamoxifen-treated breast cancer patients: findings from the National Surgical Adjuvant Breast and Bowel Project (NSABP) B-14. J Natl Cancer Inst. 1994;86(7):527-537.

80. van Leeuwen FE, Benraadt J, Coebergh JW, et al. Risk of endometrial cancer after tamoxifen treatment of breast cancer. Lancet. 1994;343(8895):448-452.

81. Effects of adjuvant tamoxifen and of cytotoxic therapy on mortality in early breast cancer. An overview of 61 randomized trials among 28,896 women. Early Breast Cancer Trialists' Collaborative Group. N Engl J Med. 1988;319(26):1681-1692.

82. Early Breast Cancer Trialists' Collaborative Group (EBCTCG). Effects of chemotherapy and hormonal therapy for early breast cancer on recurrence and 15-year survival: an overview of the randomised trials. Lancet. 2005;365(9472):1687-1717.

83. Sasaki H, Nishii H, Takahashi H, et al. Mutation of the Ki-ras protooncogene in human endometrial hyperplasia and carcinoma. Cancer Res. 1993;53(8):1906-1910.

84. Deligdisch L. Effects of hormone therapy on the endometrium. Modern Pathol. 1993;6(1):94-106.

85. Hard GC, Iatropoulos MJ, Jordan K, et al. Major difference in the hepatocarcinogenicity and DNA adduct forming ability between toremifene and tamoxifen in female $\mathrm{Crl}: \mathrm{CD}(\mathrm{BR})$ rats. Cancer Res. 1993;53(19):4534-4541.

86. Williams GM, Latropoulos MJ, Djordjevic MV, Kaltenberg OP. The triphenylethylene drug tamoxifen is a strong liver carcinogen in the rat. Carcinogenesis. 1993;14(2):315-317.

87. Hirsimäki P, Hirsimäki Y, Nieminen L, Payne BJ. Tamoxifen induces hepatocellular carcinoma in rat liver: a 1-year study with two antiestrogens. Arch Toxicol. 1993;67(1):49-54.

88. Gennari L, Merlotti D, Stolakis K, Nuti R. Pharmacokinetic evaluation of toremifene and its clinical implications for the treatment of osteoporosis. Expert Opin Drug Metab Toxicol. 2012;8(4): $505-513$.

89. Gennari L, Merlotti D, Valleggi F, Martini G, Nuti R. Selective estrogen receptor modulators for postmenopausal osteoporosis: current state of development. Drugs Aging. 2007;24(5):361-379. 
90. Qin T, Yuan ZY, Peng RJ, et al. Efficacy and tolerability of toremifene and tamoxifen therapy in premenopausal patients with operable breast cancer: a retrospective analysis. Curr Oncol. 2013;20(4): 196-204.

91. Shibutani S, Ravindernath A, Terashima I, et al. Mechanism of lower genotoxicity of toremifene compared with tamoxifen. Cancer Res. 2001;61(10):3925-3931.

92. Li D, Dragan Y, Jordan VC, Wang M, Pitot HC. Effects of chronic administration of tamoxifen and toremifene on DNA adducts in rat liver, kidney, and uterus. Cancer Res. 1997;57(8):1438-1441.

93. Shibutani S, Suzuki N, Laxmi YR, et al. Identification of tamoxifen-DNA adducts in monkeys treated with tamoxifen. Cancer Res. 2003; 63(15):4402-4406.

94. Kangas L. Introduction to toremifene. Breast Cancer Res Treat. 1990;16 Suppl:S3-S7.

95. Wallén M, Tomás E, Visakorpi T, Holli K, Mäenpää J. Endometrial K-ras mutations in postmenopausal breast cancer patients treated with adjuvant tamoxifen or toremifene. Cancer Chemother Pharmacol. 2005;55(4):343-346.

96. Oksa S, Luukkaala T, Mäenpää J. Toremifene for premenstrual mastalgia: a randomised, placebo-controlled crossover study. BJOG. 2006;113(6):713-718.

97. Gottardis MM, Jordan VC. Antitumor actions of keoxifene and tamoxifen in the N-nitrosomethylurea-induced rat mammary carcinoma model. Cancer Res. 1987;47(15):4020-4024.

98. Smith MR, Malkowicz SB, Chu F, et al. Toremifene increases bone mineral density in men receiving androgen deprivation therapy for prostate cancer: interim analysis of a multicenter phase 3 clinical study. J Urol. 2008;179(1):152-155.

99. di Salle E, Zaccheo T, Ornati G. Antiestrogenic and antitumor properties of the new triphenylethylene derivative toremifene in the rat. J Steroid Biochem. 1990;36(3):203-206.

100. Hasmann M, Rattel B, Löser R. Preclinical data for Droloxifene. Cancer Lett. 1994;84(2):101-116.

101. Eppenberger U, Wosikowski K, Küng W. Pharmacologic and biologic properties of droloxifene, a new antiestrogen. Am J Clin Oncol. 1991;14 Suppl 2:S5-S14.

102. Chen H, Tritton TR, Kenny N, Absher M, Chiu JF. Tamoxifen induces TGF-beta 1 activity and apoptosis of human MCF-7 breast cancer cells in vitro. J Cell Biochem. 1996;61(1):9-17.

103. Buzdar AU, Kau S, Hortobagyi GN, et al. Phase I trial of droloxifene in patients with metastatic breast cancer. Cancer Chemother Pharmacol. 1994;33(4):313-316.

104. Bruning PF. Droloxifene, a new anti-oestrogen in postmenopausal advanced breast cancer: preliminary results of a double-blind dosefinding phase II trial. Eur J Cancer. 1992;28A(8-9):1404-1407.

105. Haarstad H, Gundersen S, Wist E, Raabe N, Mella O, Kvinnsland S. Droloxifene - a new anti-estrogen. A phase II study in advanced breast cancer. Acta Oncol. 1992;31(4):425-428.

106. Buzdar A, Hayes D, El-Khoudary A, et al. Phase III randomized trial of droloxifene and tamoxifen as first-line endocrine treatment of ER/PgR-positive advanced breast cancer. Breast Cancer Res Treat. 2002;73(2):161-175

107. Lien EA, Solheim E, Ueland PM. Distribution of tamoxifen and its metabolites in rat and human tissues during steady-state treatment. Cancer Res. 1991;51(18):4837-4844.

108. Helle, SI, Anker GB, Tally M, Hall K, Lønning PE. Influence of droloxifene on plasma levels of insulin-like growth factor (IGF)-I, Pro-IGF-IIE, insulin-like growth factor binding protein (IGFBP)-1 and IGFBP-3 in breast cancer patients. J Steroid Biochem Mol Biol. 1996;57(3-4):167-171.

109. McCague R, Leclercq G, Legros N, et al. Derivatives of tamoxifen. Dependence of antiestrogenicity on the 4-substituent. J Med Chem. 1989;32(12):2527-2533.

110. Chander SK, McCague R, Luqmani Y, et al. Pyrrolidino-4iodotamoxifen and 4-iodotamoxifen, new analogues of the antiestrogen tamoxifen for the treatment of breast cancer. Cancer Res. 1991;51(21):5851-5858
111. Coombes RC, Haynes BP, Dowsett M, et al. Idoxifene: report of a phase I study in patients with metastatic breast cancer. Cancer Res. 1995;55(5):1070-1074.

112. McCague R, Parr IB, Haynes BP. Metabolism of the 4-iodo derivative of tamoxifen by isolated rat hepatocytes. Demonstration that the iodine atom reduces metabolic conversion and identification of four metabolites. Biochem Pharmacol. 1990;40(10):2277-2283.

113. Osborne CK, Wiebe VJ, McGuire WL, Ciocca DR, DeGregorio MW. Tamoxifen and the isomers of 4-hydroxytamoxifen in tamoxifen-resistant tumors from breast cancer patients. J Clin Oncol; 1992;10(2):304-310.

114. Willis KJ, London DR, Ward HW, Butt WR, Lynch SS, Rudd BT. Recurrent breast cancer treated with the antioestrogen tamoxifen: correlation between hormonal changes and clinical course. Br Med J. 1977;1(6058):425-428.

115. Nuttall ME, Stroup GB, Fisher PW, Nadeau DP, Gowen M, Suva LJ. Distinct mechanisms of action of selective estrogen receptor modulators in breast and osteoblastic cells. Am J Physiol Cell Physiol. 2000;279(5):C1550-C1557.

116. Nuttall ME, Bradbeer JN, Stroup GB, et al. Idoxifene: a novel selective estrogen receptor modulator prevents bone loss and lowers cholesterol levels in ovariectomized rats and decreases uterine weight in intact rats. Endocrinology. 1998;139(12):5224-5234.

117. Johnston SR, Boeddinghaus IM, Riddler S, et al. Idoxifene antagonizes estradiol-dependent MCF-7 breast cancer xenograft growth through sustained induction of apoptosis. Cancer Res. 1999;59(15):3646-3651.

118. Johnston SR, Gumbrell LA, Evans TR, et al. A cancer research (UK) randomized phase II study of idoxifene in patients with locally advanced/metastatic breast cancer resistant to tamoxifen. Cancer Chemother Pharmacol. 2004;53(4):341-348.

119. Albertazzi P, Sharma S. Urogenital effects of selective estrogen receptor modulators: a systematic review. Climacteric. 2005;8(3):214-220.

120. Arpino G, Nair Krishnan M, Doval Dinesh C, Bardou VJ, Clark GM, Elledge RM. Idoxifene versus Tamoxifen: a randomized comparison in postmenopausal patients with metastatic breast cancer. Ann Oncol. 2003;14(2):233-241.

121. Buzdar AU, Marcus C, Holmes F, Hug V, Hortobagyi G. Phase II evaluation of Ly156758 in metastatic breast cancer. Oncology. 1988;45(5):344-345.

122. Jordan VC, Phelps E, Lindgren JU. Effects of anti-estrogens on bone in castrated and intact female rats. Breast Cancer Res Treat. 1987;10(1):31-35.

123. Black LJ, Sato M, Rowley ER, et al. Raloxifene (LY139481 HCI) prevents bone loss and reduces serum cholesterol without causing uterine hypertrophy in ovariectomized rats. $J$ Clin Invest. 1994;93(1):63-69.

124. Sato M, Kim J, Short LL, Slemenda CW, Bryant HU. Longitudinal and cross-sectional analysis of raloxifene effects on tibiae from ovariectomized aged rats. J Pharmacol Exp Ther. 1995;72(3):1252-1259.

125. Yu L, Liu H, Li W, et al. Oxidation of raloxifene to quinoids: potential toxic pathways via a diquinone methide and o-quinones. Chem Res Toxicol. 2004;17(7):879-888.

126. Ettinger B, Black DM, Mitlak BH, et al. Reduction of vertebral fracture risk in postmenopausal women with osteoporosis treated with raloxifene: results from a 3-year randomized clinical trial. Multiple Outcomes of Raloxifene Evaluation (MORE) Investigators. JAMA. 1999;282(7):637-645.

127. Cummings SR, Eckert S, Krueger KA, et al. The effect of raloxifene on risk of breast cancer in postmenopausal women: results from the MORE randomized trial. Multiple Outcomes of Raloxifene Evaluation. JAMA. 1999;281(23):2189-2197.

128. DeMichele A, Troxel AB, Berlin JA, et al. Impact of raloxifene or Tamoxifen use on endometrial cancer risk: a population-based casecontrol study. J Clin Oncol. 2008;26(25):4151-4159.

129. Martino S, Cauley JA, Barrett-Connor E, et al. Continuing outcomes relevant to Evista: breast cancer incidence in postmenopausal osteoporotic women in a randomized trial of raloxifene. J Natl Cancer Inst. 2004;96(23):1751-1761. 
130. Goldstein SR. Update on raloxifene to prevent endometrial-breast cancer. Eur J Cancer. 2000;36 Suppl 4:S54-S56.

131. Dardes RC, Bentrem D, O'Regan RM, Schafer JM, Jordan VC. Effects of the new selective estrogen receptor modulator LY353381.HCl (Arzoxifene) on human endometrial cancer growth in athymic mice. Clinical Cancer Res. 2001;7(12):4149-4155.

132. Sporn MB. Arzoxifene: a promising new selective estrogen receptor modulator for clinical chemoprevention of breast cancer. Clin Cancer Res. 2004;10(16):5313-5315.

133. Jackson LR, Cheung KL, Buzdar AU, Robertson JF. Arzoxifene: the evidence for its development in the management of breast cancer. Core Evid. 2008;2(4):251-258.

134. Palkowitz AD, Glasebrook AL, Thrasher KJ, et al. Discovery and synthesis of [6-hydroxy-3-[4-[2-(1-piperidinyl)ethoxy]phenoxy]-2(4-hydroxyphenyl)]b enzo[b]thiophene: a novel, highly potent, selective estrogen receptor modulator. J Med Chem. 1997;40(10):1407-1416.

135. Suh N, Glasebrook AL, Palkowitz AD, et al. Arzoxifene, a new selective estrogen receptor modulator for chemoprevention of experimental breast cancer. Cancer Res. 2001;61(23):8412-8415.

136. Liu H, Liu J, van Breemen RB, Thatcher GR, Bolton JL. Bioactivation of the selective estrogen receptor modulator desmethylated arzoxifene to quinoids: 4'-fluoro substitution prevents quinoid formation. Chem Res Toxicol. 2005;18(2):162-173.

137. Freddie CT, Larsen SS, Bartholomaeussen M, Lykkesfeldt AE. The effect of the new SERM arzoxifene on growth and gene expression in MCF-7 breast cancer cells. Mol Cell Endocrinol. 2004;219(1-2):27-36.

138. Chen Q, Ngui JS, Doss GA, et al. Cytochrome P450 3A4-mediated bioactivation of raloxifene: irreversible enzyme inhibition and thiol adduct formation. Chem Res Toxicol. 2002;15(7):907-914.

139. Pearson JT, Wahlstrom JL, Dickmann LJ, et al. Differential timedependent inactivation of P450 3A4 and P450 3A5 by raloxifene: a key role for $\mathrm{C} 239$ in quenching reactive intermediates. Chem Res Toxicol. 2007;20(12):1778-1786.

140. Yukinaga H, Takami T, Shioyama SH, et al. Identification of cytochrome P450 3A4 modification site with reactive metabolite using linear ion trap-Fourier transform mass spectrometry. Chem Res Toxicol. 2007;20(10):1373-1378.

141. Münster PN, Buzdar A, Dhingra K, et al. Phase I study of a thirdgeneration selective estrogen receptor modulator, LY353381.HCL, in metastatic breast cancer. J Clin Oncol. 2001;19(7):2002-2009.

142. Fabian CJ, Kimler BF, Anderson JR, et al. Phase II breast cancer chemoprevention trial of the third generation selective estrogen receptor modulator arzoxifene. J Clin Oncol. 2006;24(18s):1001.

143. Buzdar A, O'Shaughnessy JA, Booser DJ, et al. Phase II, randomized, double-blind study of two dose levels of arzoxifene in patients with locally advanced or metastatic breast cancer. J Clin Oncol. 2003;21(6):1007-1014.

144. Baselga J, Llombart-Cussac A, Bellet M, et al. Randomized, doubleblind, multicenter trial comparing two doses of arzoxifene (LY353381) in hormone-sensitive advanced or metastatic breast cancer patients. Ann Oncol. 2003;14(9):1383-1390.

145. Ke HZ, Qi H, Crawford DT, Chidsey-Frink KL, Simmons HA, Thompson DD. Lasofoxifene (CP-336,156), a selective estrogen receptor modulator, prevents bone loss induced by aging and orchidectomy in the adult rat. Endocrinology. 2000;141(4):1338-1344.

146. Rosati RL, Da Silva Jardine P, Cameron KO, et al. Discovery and preclinical pharmacology of a novel, potent, nonsteroidal estrogen receptor agonist/antagonist, CP-336156, a diaryltetrahydronaphthalene. J Med Chem. 1998;41(16):2928-2931.

147. Ke HZ, Paralkar VM, Grasser WA, et al. Effects of CP-336,156, a new, nonsteroidal estrogen agonist/antagonist, on bone, serum cholesterol, uterus and body composition in rat models. Endocrinology. 1998;139(4):2068-2076.

148. Stump AL, Kelley KW, Wensel TM. Bazedoxifene: a third-generation selective estrogen receptor modulator for treatment of postmenopausal osteoporosis. Ann Pharmacother. 2007;41(5):833-839.
149. Chaki O. [Next generation selective estrogen receptor modulators]. Clin Calcium. 2006;16(1):145-152. Japanese.

150. Draper MW, Plouffe L Jr. Endometrial effects of bazedoxifene acetate, a novel selective estrogen receptor modulator, in postmenopausal women. Obstet Gynecol. 2005;106(5 Pt 1):1110-1111.

151. McClung MR, Siris E, Cummings S, et al. Prevention of bone loss in postmenopausal women treated with lasofoxifene compared with raloxifene. Menopause. 2006;13(3):377-386.

152. Ke HZ, Foley GL, Simmons HA, Shen V, Thompson DD. Long-term treatment of lasofoxifene preserves bone mass and bone strength and does not adversely affect the uterus in ovariectomized rats. Endocrinology. 2004;145(4):1996-2005.

153. Michalsen BT, Gherezghiher TB, Choi J, et al. Selective estrogen receptor modulator (SERM) lasofoxifene forms reactive quinones similar to estradiol. Chem Res Toxicol. 2012;25(7):1472-1483.

154. Peterson GM, Naunton M, Tichelaar LK, Gennari L. Lasofoxifene: selective estrogen receptor modulator for the prevention and treatment of postmenopausal osteoporosis. Ann Pharmacother. 2011;45(4): 499-509.

155. Cummings SR, Ensrud K, Delmas PD, et al. Lasofoxifene in postmenopausal women with osteoporosis. $N$ Engl J Med. 2010; 362(8):686-696.

156. Dnistrian AM, Schwartz MK, Greenberg EJ, Smith CA, Schwartz DC Effect of tamoxifen on serum cholesterol and lipoproteins during chemohormonal therapy. Clin Chim Acta. 1993;223(1-2):43-52.

157. Gruber C, Gruber D. Bazedoxifene (Wyeth). Curr Opin Investig Drugs. 2004;5(10):1086-1093.

158. Chines AA, Komm BS. Bazedoxifene acetate: a novel selective estrogen receptor modulator for the prevention and treatment of postmenopausal osteoporosis. Drugs Today (Barc). 2009;45(7):507-520.

159. Miller CP, Collini MD, Tran BD, et al. Design, synthesis, and preclinical characterization of novel, highly selective indole estrogens. J Med Chem. 2001;44(11):1654-1657.

160. Shen L, Ahmad S, Park S, et al. In vitro metabolism, permeability, and efflux of bazedoxifene in humans. Drug Metab Dispos. 2010; 38(9):1471-1479.

161. Komm BS, Lyttle CR. Developing a SERM: stringent preclinical selection criteria leading to an acceptable candidate (WAY-140424) for clinical evaluation. Ann N Y Acad Sci. 2001;949:317-326.

162. Ronkin S, Northington R, Baracat E, et al. Endometrial effects of bazedoxifene acetate, a novel selective estrogen receptor modulator, in postmenopausal women. Obstet Gynecol. 2005;105(6): 1397-1404.

163. Silverman SL, Christiansen C, Genant HK, et al. Efficacy of bazedoxifene in reducing new vertebral fracture risk in postmenopausal women with osteoporosis: results from a 3-year, randomized, placebo-, and active-controlled clinical trial. J Bone Miner Res. 2008;23(12):1923-1934.

164. Silverman SL, Chines AA, Kendler DL, et al. Sustained efficacy and safety of bazedoxifene in preventing fractures in postmenopausal women with osteoporosis: results of a 5-year, randomized, placebocontrolled study. Osteoporos Int. 2012;23(1):351-363.

165. Kanis JA, Johansson H, Oden A, McCloskey EV. Bazedoxifene reduces vertebral and clinical fractures in postmenopausal women at high risk assessed with FRAX. Bone. 2009;44(6):1049-1054.

166. Pickar JH, Yeh IT, Bachmann G, Speroff L. Endometrial effects of a tissue selective estrogen complex containing bazedoxifene/conjugated estrogens as a menopausal therapy. Fertil Steril. 2009;92(3): 1018-1024.

167. Lindsay R, Gallagher JC, Kagan R, Pickar JH, Constantine G. Efficacy of tissue-selective estrogen complex of bazedoxifene/conjugated estrogens for osteoporosis prevention in at-risk postmenopausal women. Fertil Steril. 2009;92(3):1045-1052.

168. Archer DF, Pinkerton JV, Utian WH, et al. Bazedoxifene a selective estrogen receptor modulator: effects on the endometrium ovaries and breast from a randomized controlled trial in osteoporotic postmenopausal women. Menopause. 2009;16(6):1109-1015. 
169. Pinkerton JV, Archer DF, Utian WH, et al. Bazedoxifene effects on the reproductive tract in postmenopausal women at risk for osteoporosis. Menopause. 2009;16(6):1102-1108.

170. Harvey JA, Holm MK, Ranganath R, Guse PA, Trott EA, Helzner E. The effects of bazedoxifene on mammographic breast density in postmenopausal women with osteoporosis. Menopause. 2009;16(6):1193-1196.

171. Miller PD, Chines AA, Christiansen C, et al. Effects of bazedoxifene on BMD and bone turnover in postmenopausal women: 2-yr results of a randomized, double-blind, placebo-, and active-controlled study. $J$ Bone Miner Res. 2008;23(4):525-535.

172. Geiser AG, Hummel CW, Draper MW, et al. A new selective estrogen receptor modulator with potent uterine antagonist activity, agonist activity in bone, and minimal ovarian stimulation. Endocrinology. 2005;146(10):4524-4535.

173. Sato M, Rippy MK, Bryant HU. Raloxifene, tamoxifen, nafoxidine, or estrogen effects on reproductive and nonreproductive tissues in ovariectomized rats. FASEB J. 1996;10(8):905-912.

174. Dowers TS, Qin ZH, Thatcher GR, Bolton JL. Bioactivation of Selective Estrogen Receptor Modulators (SERMs). Chem Res Toxicol. 2006;19(9):1125-1137.

175. Sarabia SF, Zhu BT, Kurosawa T, Tohma M, Liehr JG. Mechanism of cytochrome P450-catalyzed aromatic hydroxylation of estrogens. Chem Res Toxicol. 1997;10(7):767-771.

176. Gherezghiher TB, Michalsen B, Chandrasena RE, et al. The naphthol selective estrogen receptor modulator (SERM), LY2066948, is oxidized to an o-quinone analogous to the naphthol equine estrogen, equilenin. Chem Biol Interact. 2012;196(1-2):1-10.

177. MacGregor Schafer J, Liu H, Bentrem DJ, Zapf JW, Jordan VC. Allosteric silencing of activating function 1 in the 4-hydroxytamoxifen estrogen receptor complex is induced by substituting glycine for aspartate at amino acid 351. Cancer Res. 2000;60(18):5097-5105.

178. Liu H, Park WC, Bentrem DJ, et al. Structure-function relationships of the raloxifene-estrogen receptor-alpha complex for regulating transforming growth factor-alpha expression in breast cancer cells. J Biol Chem. 2002;277(11):9189-9198.

179. Schwartzbaum JA, Hulka BS, Fowler WC Jr, Kaufman DG, Hoberman D. The influence of exogenous estrogen use on survival after diagnosis of endometrial cancer. Am J Epidemiol. 1987;126(5):851-860.

180. DeGregorio MW, Maenpaa JU, Wiebe VJ. Tamoxifen for the prevention of breast cancer: no. Important Adv Oncol. 1995;175-185.

181. Wilder JL, Shajahan S, Khattar NH, et al. Tamoxifen-associated malignant endometrial tumors: pathologic features and expression of hormone receptors estrogen-alpha, estrogen-beta and progesterone; a case controlled study. Gynecol Oncol. 2004;92(2):553-558.

182. Davies R, Oreffo VI, Martin EA, et al. Tamoxifen causes gene mutations in the livers of lambda/lacI transgenic rats. Cancer Res. 1997;57(7): $1288-1293$.

183. Han XL, Liehr JG. Induction of covalent DNA adducts in rodents by tamoxifen. Cancer Res. 1992;52(5):1360-1363.
184. White IN, de Matteis F, Davies A, et al. Genotoxic potential of tamoxifen and analogues in female Fischer F344/n rats, DBA/2 and C57BL/6 mice and in human MCL-5 cells. Carcinogenesis. 1992;13(12):2197-2203.

185. Bolton JL, Thatcher GR. Potential mechanisms of estrogen quinone carcinogenesis. Chem Res Toxicol. 2008;21(1):93-101.

186. Jordan VC. Metabolites of tamoxifen in animals and man: identification, pharmacology, and significance. Breast Cancer Res Treat. 1982;2(2):123-138

187. Potter GA, McCague R, Jarman M. A mechanistic hypothesis for DNA adduct formation by tamoxifen following hepatic oxidative metabolism. Carcinogenesis. 1994;15(3):439-442.

188. Sharma M, Shubert DE, Lewis J, McGarrigle BP, Bofinger DP, Olson JR. Biotransformation of tamoxifen in a human endometrial explant culture model. Chem Biol Interact. 2003;146(3):237-249.

189. Fan PW, Zhang F, Bolton JL. 4-Hydroxylated metabolites of the antiestrogens tamoxifen and toremifene are metabolized to unusually stable quinone methides. Chem Res Toxicol. 2000;13(1):45-52.

190. Shibutani S, Dasaradhi L. Miscoding potential of tamoxifen-derived DNA adducts: alpha-(N2-deoxyguanosinyl)tamoxifen. Biochemistry. 1997;36(42):13010-13017.

191. Terashima I, Suzuki N, Shibutani S. Mutagenic potential of alpha-(N2-deoxyguanosinyl)tamoxifen lesions, the major DNA adducts detected in endometrial tissues of patients treated with tamoxifen. Cancer Res. 1999;59(9):2091-2095.

192. ShibutaniS, Suzuki N, TerashimaI, SugarmanSM, GrollmanAP, PearlML. Tamoxifen-DNA adducts detected in the endometrium of women treated with tamoxifen. Chem Res Toxicol. 1999;12(7):646-653.

193. Shibutani S, Ravindernath A, Suzuki N, et al. Identification of tamoxifen-DNA adducts in the endometrium of women treated with tamoxifen. Carcinogenesis. 2000;21(8):1461-1467.

194. Shibutani S, Reardon JT, Suzuki N, Sancar A. Excision of tamoxifenDNA adducts by the human nucleotide excision repair system. Cancer Res. 2000;60(10):2607-2610.

195. Kawamura Y, Hayashi H, Kurata Y, Hiratsuka K, Masumura K, Nohmi T. Evaluation of the genotoxicity of tamoxifen in the liver and kidney of F344 gpt delta transgenic rat in 3-week and 13-week repeated dose studies. Toxicology. 2013;312:56-62.

196. Zhang F, Fan PW, Liu X, Shen L, van Breeman RB, Bolton JL. Synthesis and reactivity of a potential carcinogenic metabolite of Tamoxifen: 3,4-dihydroxyTamoxifen-o-quinone. Chem Res Toxicol. 2000;13(1):53-62.

197. Marques MM, Beland FA. Identification of tamoxifen-DNA adducts formed by 4-hydroxytamoxifen quinone methide. Carcinogenesis. 1997;18(10):1949-1954.

198. Monks TJ, Hanzlik RP, Cohen GM, Ross D, Graham DG. Quinone chemistry and toxicity. Toxicol Appl Pharmacol. 1992;112(1):2-16.

199. Beland FA, McDaniel LP, Marques MM. Comparison of the DNA adducts formed by Tamoxifen and 4-hydroxyTamoxifen in vivo. Carcinogenesis. 1999;20(3):471-477.
Clinical Interventions in Aging

\section{Publish your work in this journal}

Clinical Interventions in Aging is an international, peer-reviewed journal focusing on evidence-based reports on the value or lack thereof of treatments intended to prevent or delay the onset of maladaptive correlates of aging in human beings. This journal is indexed on PubMed Central, MedLine,
Dovepress

CAS, Scopus and the Elsevier Bibliographic databases. The manuscript management system is completely online and includes a very quick and fair peer-review system, which is all easy to use. Visit http://www.dovepress. com/testimonials.php to read real quotes from published authors. 